Article

\title{
Inversion of the Photogalvanic Effect of Conductive Polymers by Porphyrin Dopants
}

\author{
Alexey A. Petrov, Daniil A. Lukyanov (D, Oleg A. Kopytko, Julia V. Novoselova, Elena V. Alekseeva and \\ Oleg V. Levin *(D)
}

check for

updates

Citation: Petrov, A.A.;

Lukyanov, D.A.; Kopytko, O.A.;

Novoselova, J.V.; Alekseeva, E.V.;

Levin, O.V. Inversion of the

Photogalvanic Effect of Conductive

Polymers by Porphyrin Dopants.

Catalysts 2021, 11, 729. https://

doi.org/10.3390/catal11060729

Academic Editor: Vincenzo Baglio

Received: 15 May 2021

Accepted: 12 June 2021

Published: 12 June 2021

Publisher's Note: MDPI stays neutral with regard to jurisdictional claims in published maps and institutional affiliations.

Copyright: (C) 2021 by the authors Licensee MDPI, Basel, Switzerland. This article is an open access article distributed under the terms and conditions of the Creative Commons Attribution (CC BY) license (https:// creativecommons.org/licenses/by/ $4.0 /)$
Institute of Chemistry, Saint Petersburg State University, University Embankment, 7/9, 199034 St. Petersburg, Russia; barmalei01@mail.ru (A.A.P.); lda93@yandex.ru (D.A.L.); kopytko2015@yandex.ru (O.A.K.); julivit.n@gmail.com (J.V.N.); alekseeva_ev@yahoo.com (E.V.A.)

* Correspondence: o.levin@spbu.ru; Tel.: +7-812-4286900

\begin{abstract}
Conductive polymers are widely used as active and auxiliary materials for organic photovoltaic cells due to their easily tunable properties, high electronic conductivity, and light absorption. Several conductive polymers show the cathodic photogalvanic effect in pristine state. Recently, photoelectrochemical oxygen reduction has been demonstrated for nickel complexes of Salen-type ligands. Herein, we report an unexpected inversion of the photogalvanic effect caused by doping of the NiSalen polymers with anionic porphyrins. The observed effect was studied by means of UV-Vis spectroscopy, cyclic voltammetry and chopped light chronoamperometry. While pristine NiSalens exhibit cathodic photopolarization, doping with porphyrins inverts the polarization. As a result, photoelectrochemical oxidation of the ascorbate proceeds smoothly on the NiSalen electrode doped with zinc porphyrins. The highest photocurrents were observed on NiSalen polymer with $o$-phenylene imine bridge, doped with anionic zinc porphyrin. Assuming this, porphyrin serves both as a catalytic center for the oxidation of ascorbate and an internal electron donor, facilitating the photoinduced charge transport and anodic depolarization.
\end{abstract}

Keywords: photocurrent; NiSalen; porphyrin; electrodeposition; photovoltaics

\section{Introduction}

Conductive polymers $(\mathrm{CP})$ are a unique class of materials, which combine the benefits of organic materials and electronic conductors. Since their discovery, the CPs have been widely used not only as a replacement to inorganic conductors [1-3], but as advanced functional materials for electronics [4-6], electrochromic devices [6-9], sensing [10-12], and energy storage [13-18]. One of the main applications of the CPs is in photovoltaics, where they are used as donor phase [19-21] and hole transporting layer [22] materials in organic photovoltaic devices or counter electrode materials for dye-sensitized solar cells (DSSC) [23,24].

At the same time, an intrinsic photogalvanic effect is known for polythiophene CPs, which indicates the potential of these materials as active layers in DSSC-type architectures $[25,26]$. It was shown that the photocurrents of polythiophenes depended strongly on the nature of anionic dopant [27] and film morphology [28]. An increase of the photocurrent was observed with increasing polymer orderliness and rigidity as well as decreasing dopant mobility [29]. Based on this knowledge, recently, the photogalvanic effect on highly rigid NiSalen-type conductive polymers has also been discovered [30] and implemented for the photoelectrochemical oxygen reaction reduction reaction (ORR) cell to produce hydrogen peroxide [31].

The electrochemical and optical properties of the CPs strongly depend on the nature of its anionic dopants, which may be illustrated by the comparison of commercial PEDOT:PSS material and PEDOT doped with low molecular ions [32]. The effect of anion dopant is realized through the tuning of the polymer morphology [33] or ion diffusion 
parameters [34,35]. However, an anionic dopation phenomenon of the CPs may be exploited to anchor the functional fragments into a $\mathrm{CP}$ to enhance its properties. For example, poly (terthiophene) doped with anionic manganese porphyrin exhibits an outstanding photoelectrocatalytic performance for electrochemical water splitting [36].

Herein, we report an unexpected effect of dopation of the anionic porphyrin in the NiSalen-type conductive polymers (Figure 1), which was expected to increase the photogalvanic effect of the polymer by an antenna approach, analogous to the photosynthetic systems [37-39]. Surprisingly, an introduction of the porphyrin anions was found to decrease the ORR performance, previously observed on the pristine films [31], even when irradiated at the Soret band of the porphyrin. At the same time, in the presence of the electron donor (ascorbate, $\mathrm{Asc}^{-}$) in the electrolyte, porphyrin-doped films exhibit an enhanced anodic photogalvanic effect. The origin of the observed effect was investigated by electrochemical methods.

(a)

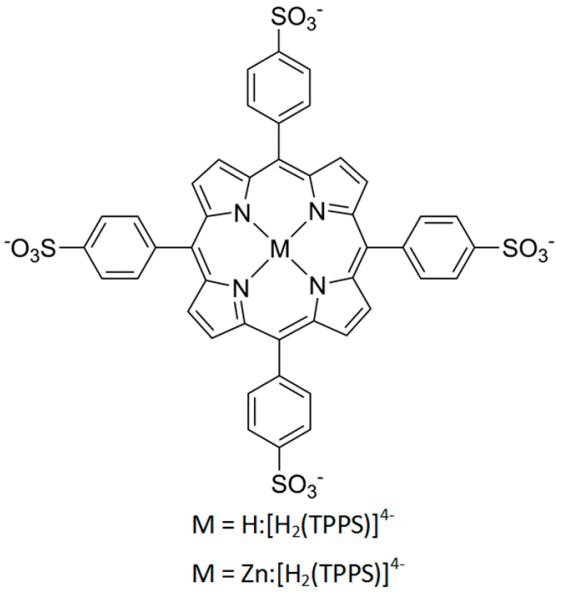

(b)
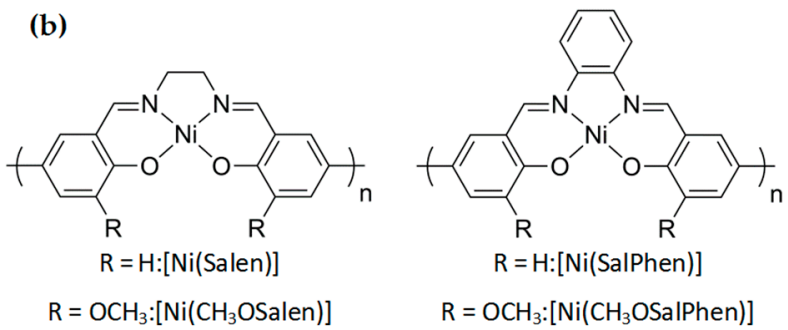

Figure 1. (a) Structure of the NiSalen polymers; (b) Structure of the MTPPS porphyrins, employed in the present study.

\section{Results and Discussion}

Initially, the free base porphyrin salt $\left[\mathrm{Bu}_{4} \mathrm{~N}_{4}\left[\mathrm{H}_{2}\right.\right.$ (TPPS)] was used as an anionic

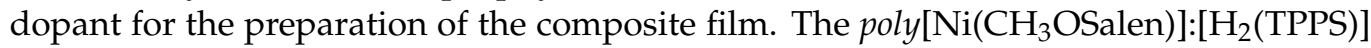
film was deposited onto the ITO substrate from the solution of $\left[\mathrm{Ni}\left(\mathrm{CH}_{3} \mathrm{OSalen}\right)\right]$ with the $\left[\mathrm{Bu}_{4} \mathrm{~N}_{4}\left[\mathrm{H}_{2}\right.\right.$ (TPPS)] as a supporting electrolyte (Figure S5). Freshly prepared films exhibited the distinctive features on UV-Vis, attributed to the presence of poly $\left[\mathrm{Ni}\left(\mathrm{CH}_{3} \mathrm{OSalen}\right)\right]$ polymer and $\left[\mathrm{H}_{2} \text { (TPPS) }\right]^{4-}$ particles (Figure 2a), but during the $\mathrm{CV}$ measurements or even storage in the reduced state, unexpected spectral changes were noticed. A New Soret band emerged at $460 \mathrm{~nm}$, accompanied by an intensive Q-band at $660 \mathrm{~nm}$ (Figure 2b), which indicates the formation of the nickel porphyrin complex accompanied by demetallation of the poly[ $\left.\mathrm{Ni}\left(\mathrm{CH}_{3} \mathrm{OSalen}\right)\right]$ units by the strongly coordinating porphyrin ligand. Considering the sluggish kinetics for the insertion of nickel into meso-tetraaryl porphyrins [40], this fact may be explained by the participation of the reduced nickel in this process [41]. 

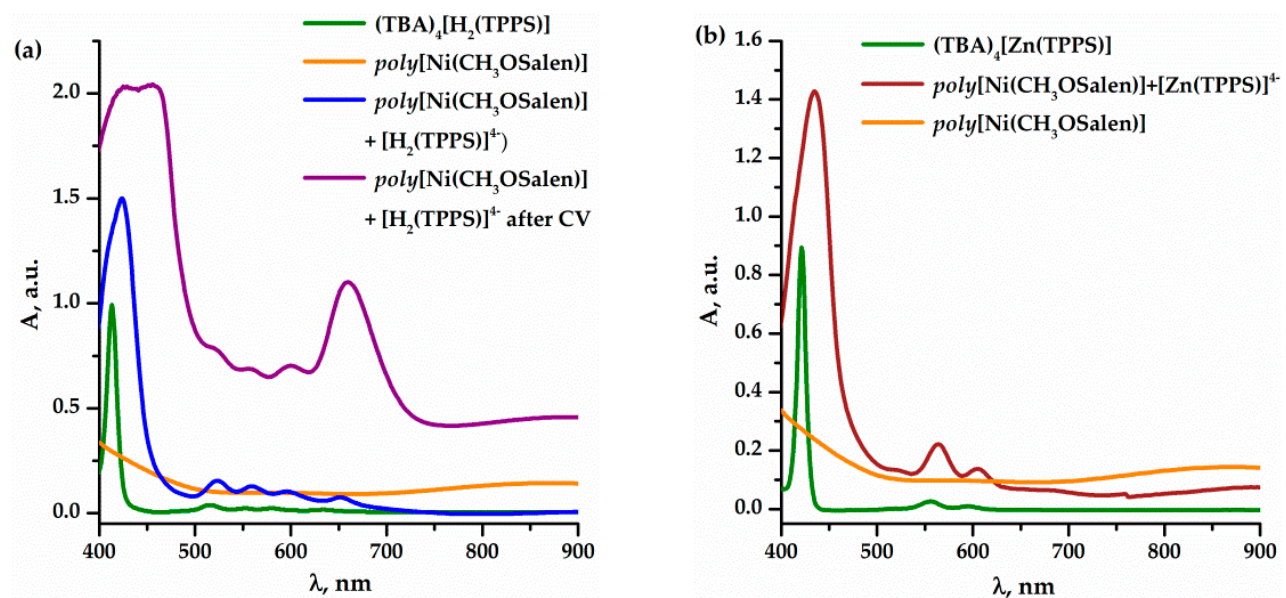

Figure 2. (a) UV-Vis spectra of $2 \times 10^{-6} \mathrm{M}\left[\mathrm{Bu}_{4} \mathrm{~N}_{4}\left[\mathrm{H}_{2}\right.\right.$ (TPPS)] aqueous solution, pristine poly[ $\left.\mathrm{Ni}\left(\mathrm{CH}_{3} \mathrm{OSalen}\right)\right]$, poly[Ni( $\left.\left.\mathrm{CH}_{3} \mathrm{OSalen}\right)\right]:\left[\mathrm{H}_{2}\right.$ (TPPS)] films and poly[Ni( $\left.\left.\mathrm{CH}_{3} \mathrm{OSalen}\right)\right]$ :[ $\mathrm{H}_{2}$ (TPPS)] film after CV experiments; (b) UV-Vis spectra of

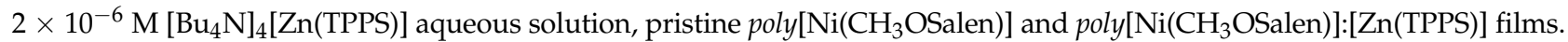

To overcome this problem, metallated porphyrin $[\mathrm{Zn}(\mathrm{TPPS})]^{4-}$ was used instead of the free base one. Indeed, the polymeric films doped with $[\mathrm{Zn}(\mathrm{TPPS})]^{4-}$ showed excellent stability during all electrochemical experiments (Figure S1).

\section{Photoelectrochemical Performance}

Porphyrin-doped polymeric films were successfully deposited for all four monomeric NiSalen-type complexes. To assess the photoelectrochemical behavior of the obtained films, light sources with $\lambda_{\max }$ at 420 and $470 \mathrm{~nm}$ were used. These wavelengths, on the one hand, lie near the maximum of the insolation spectrum of the Earth, and on the other hand, excite polyNiSalen species selectively $(470 \mathrm{~nm})$ or excite both components $(420 \mathrm{~nm})$. Previously, it was reported that polyNiSalens act as photocathodes, and in aerated solutions noticeable currents of oxygen electroreduction are observed under the illumination of photoelectrochemical cells containing such polymers [31]. However, the irradiation of obtained porphyrin - doped films used as a cathode in ORR photoelectrochemical cells with 420 and/or $470 \mathrm{~nm}$ light gave disappointing results: the cathodic currents became at least an order of magnitude lower in comparison with the corresponding pristine polyNiSalen films, and moreover, the current direction changed to anodic in case of phenylene-bridged complexes (Figure S2). The current value suffers relatively fast decay, which may indicate the depletion of electron donating particles responsible for this effect. In absence of an external electron donor, the self-oxidation of the composite film may occur, while an electron was removed from the porphyrin molecule, which is an explanation for the observed decay of the anodic current.

To disclose this unusual effect, a series of experiments were performed with an external electron donor ( $0.1 \mathrm{M}$ ascorbic acid) in the supporting electrolyte. As anticipated, sustainable anodic currents appeared upon irradiation with both wavelengths in case of porphyrin-doped films, while pristine polyNiSalen films still exhibit a diminishing cathodic current, confirming the role of porphyrin in the formation of anodic current (Figure 3). 

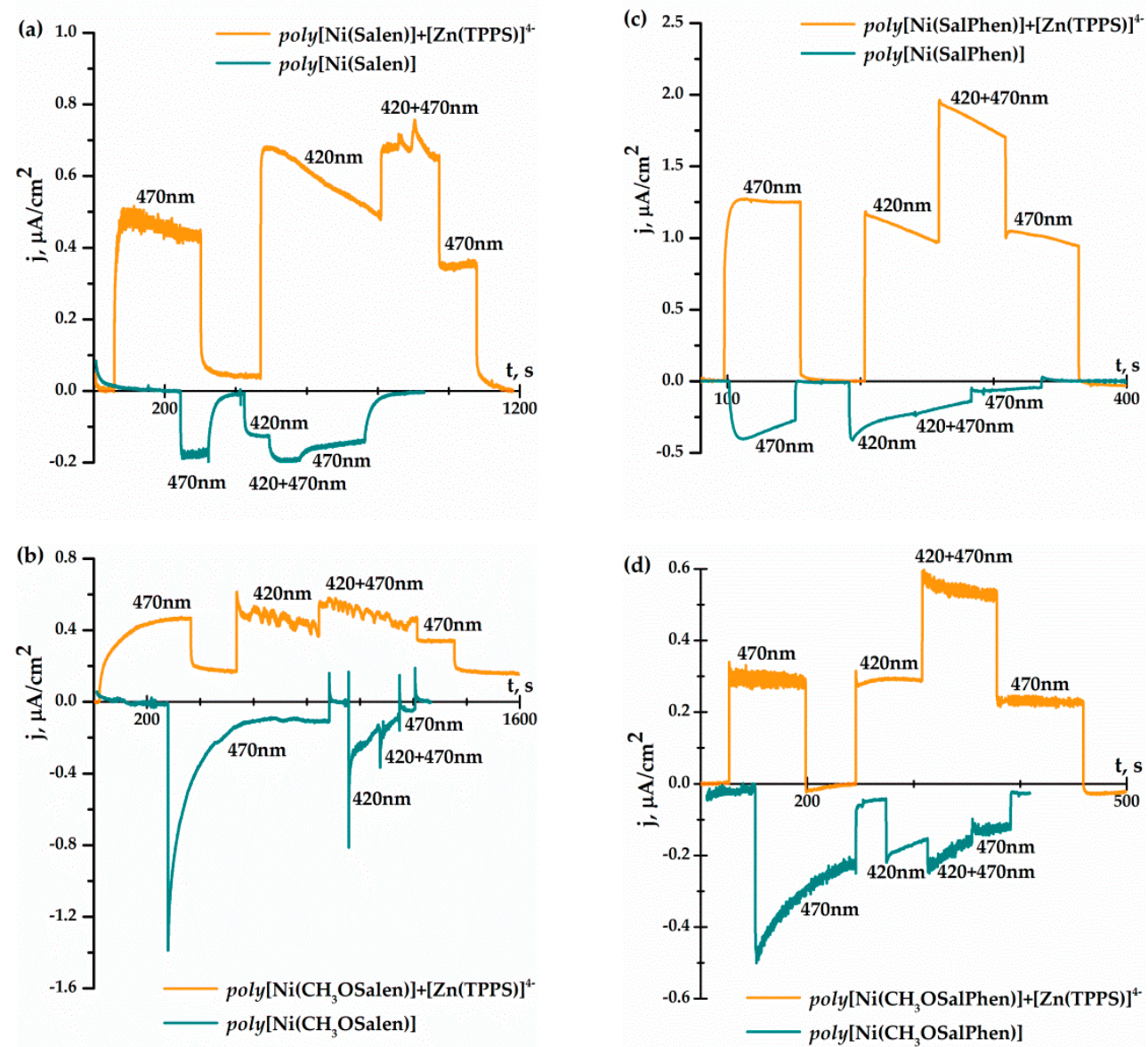

Figure 3. Anodic photocurrent by the pristine and ZnTPPS-doped (a) poly[Ni(Salen)]; (b) poly[Ni(SalPhen)]; (c) poly[Ni( $\left.\left.\mathrm{CH}_{3} \mathrm{OSalen}\right)\right]$; (d) poly[Ni( $\left.\left.\mathrm{CH}_{3} \mathrm{OSalPhen}\right)\right]$ films on ITO. Phosphate buffer, $\mathrm{Ph}=6.86,0.1 \mathrm{M}$ ascorbic acid.

The partial light absorptions of porphyrin and polymer components depend on the polymer structure, due to the unequal dopation extents and unequal absorption spectra of different polymers. To account for this, the obtained current values should be corrected for the illuminance at the specific wavelength and experimental absorption of the film at this wavelength. As a result, the following parameter, LE, was chosen as a photogalvanic performance index:

$$
L E_{\lambda}=\frac{j_{\lambda}}{\left(1-T_{\lambda}\right) E_{\lambda}}
$$

when $j_{\lambda}\left(\mathrm{A} \mathrm{cm}{ }^{-2}\right)$ is the photocurrent density, $T_{\lambda}$ is the light transmission and $E_{\lambda}$ (lux) is the illuminance at specific wavelength.

The results of both ORR and ascorbate oxidation experiments are summarized in the Table 1. The ORR reaction proceeds on the pristine polymeric films with greater efficiency compared to porphyrin-doped analogues. The most efficient at both wavelengths are poly[Ni(Salen)] films. Oxidation of the $\mathrm{Asc}^{-}$on pristine films is negligible, affording a little cathodic current attributed to a trace amounts of oxygen in solution or autoxidation of the film. In contrast, porphyrin-doped NiSalen films afford a significant anodic photogalvanic effect. For all four films, the LE at $420 \mathrm{~nm}$ is $2-2.5$ times higher than at $470 \mathrm{~nm}$, and the highest LE is observed for poly[Ni(SalPhen)]:[ZnTPPS] film, indicating the key role of the porphyrinic species in the anodic photogalvanic effect. 
Table 1. Relative light efficiencies of the films.

\begin{tabular}{|c|c|c|c|c|c|}
\hline \multirow{3}{*}{ Ni-L } & \multirow{3}{*}{$\lambda, \mathrm{nm}$} & \multicolumn{4}{|c|}{$\mathrm{LE}^{[\mathrm{a}]}, \mu \mathrm{A} \mathrm{cm}^{-2} \mathrm{Mlx}^{-1}$} \\
\hline & & $\mathrm{O}_{2}$ Reduction & Asc $^{-}$Oxidation & $\mathrm{O}_{2}$ Reduction & Asc $^{-}$Oxidation \\
\hline & & $\mathrm{Ni}-\mathrm{L}^{[\mathrm{b}]}$ & $\mathrm{Ni}-\mathrm{L}^{[\mathrm{b}]}$ & Ni-L:P $\mathbf{P}^{[c]}$ & Ni-L:P ${ }^{[c]}$ \\
\hline \multirow{2}{*}{ poly[Ni(Salen)] } & 470 & -130.4 & -2.1 & -18.0 & 7.9 \\
\hline & 420 & -174.7 & -5.6 & -17.4 & 21.1 \\
\hline \multirow{2}{*}{ poly $\left[\mathrm{NiCH}_{3} \mathrm{O}\right.$ (Salen)] } & 470 & -98.2 & -4.0 & -2.6 & 3.2 \\
\hline & 420 & -53.7 & -4.5 & -9.3 & 5.7 \\
\hline \multirow{2}{*}{ poly [Ni(SalPhen)] } & 470 & -38.8 & -1.5 & -2.1 & 33.5 \\
\hline & 420 & -120.1 & -5.3 & -2.5 & 68.3 \\
\hline \multirow{2}{*}{ poly $\left[\mathrm{Ni}\left(\mathrm{CH}_{3} \mathrm{OSalPhen}\right)\right]$} & 470 & -20.5 & -0.8 & -3.4 & 9.2 \\
\hline & 420 & -40.7 & -6.7 & -6.2 & 20.7 \\
\hline
\end{tabular}

${ }^{[\mathrm{a}]}$ calculated from the plateau or and point current; ${ }^{[\mathrm{b}]}$ polyNiSalen film; ${ }^{[\mathrm{cc}]}$ polyNiSalen $+[\mathrm{Zn}(\mathrm{TPPS})]^{4-}$.

To examine the optical linearity of the effect, two series of experiments were performed. Within the first series, films of different thickness were examined under the same conditions, including constant illuminance, while during the second series, the illuminance was varied for the single polymeric film (Figure S3). The observed photoresponse is linear vs. the illuminance intensity and film thickness (Figure 4), which indicates that the photocurrent is limited by the amount of incident photons.
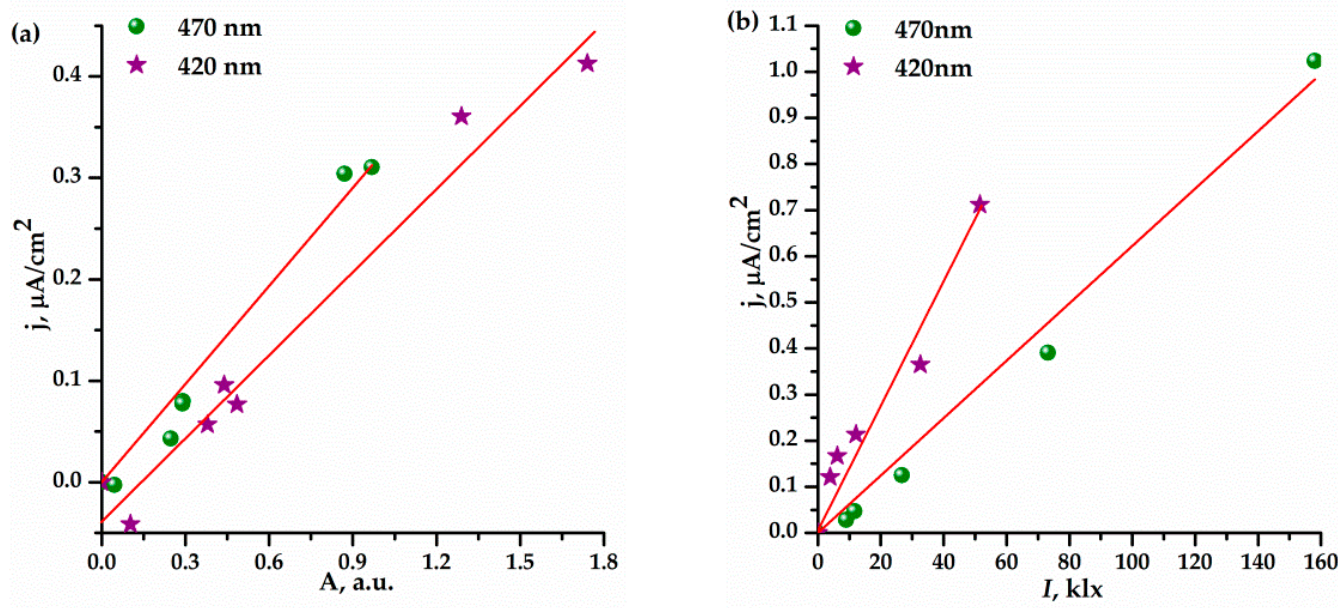

Figure 4. (a) Dependence of the photocurrent on the optical density of the poly[Ni(SalPhen)]:[Zn(TPPS)] film; (b) Dependence of the photocurrent on the illuminance of the poly[Ni(SalPhen)]:[Zn(TPPS)] film.

To understand the possible internal electron transport pathways, an energy diagram of electrochemical HOMO-LUMO levels was obtained on a basis of CV data of pristine polymeric NiSalen films and a solution of $\left[\mathrm{Bu}_{4} \mathrm{~N}_{4}[\mathrm{Zn}\right.$ (TPPS)] (Figure 5). The HOMOLUMO gap values for polymeric films were additionally verified by comparing with the optical band gaps calculated from the Tauc plots (Figure S4) [42].

According to the diagram, HOMO levels for all polymers are situated at ca. $0.9 \mathrm{~V}$ along with the HOMO of $[\mathrm{Zn}(\mathrm{TPPS})]^{4-}$, while LUMO levels strongly depend on a bridging fragment of the complex, comprising ca. $-0.9 \mathrm{~V}$ for "Phen" polymers and $-1.6 \mathrm{~V}$ for "En" polymers. The porphyrinic LUMO at $-1.31 \mathrm{~V}$ thus lies higher than the LUMO of "Phen" polymers but lower than of "En" polymers, thus the electron transfer is possible from the excited state of $[\mathrm{Zn}(\mathrm{TPPS})]^{4-}$ to the "Phen" polymers, but not to "En" ones. 


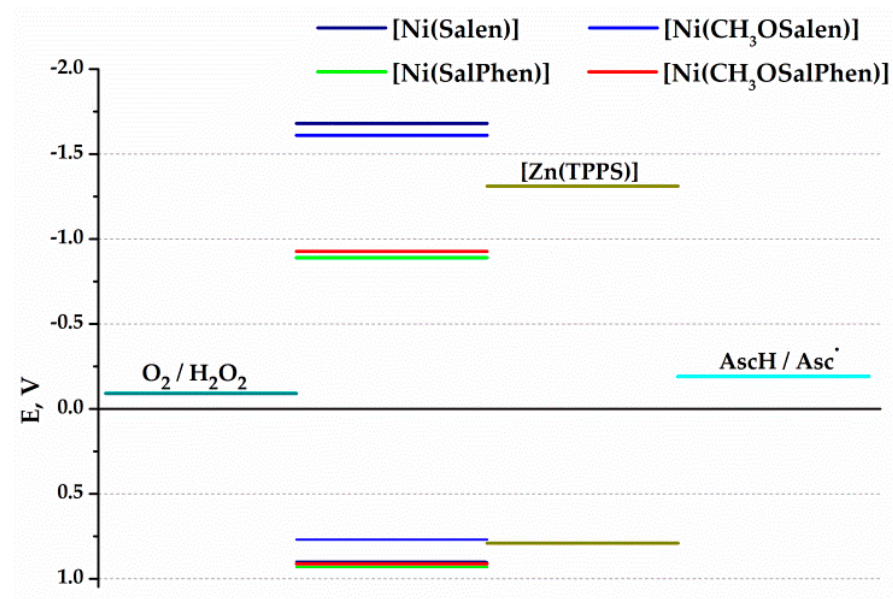

Figure 5. Electrochemical energy level diagram for NiSalen polymers, porphyrin salt, oxygen and ascorbic acid.

Based on the energy levels of the components, two plausible mechanisms for the PE oxidation of ascorbate on the poly[Ni(SalPhen)]:[ZnTPPS] electrode may be proposed, depending on the photoexcited particle. In case of [Zn(TPPS) $]^{4-}$ excitation, which should be the main excitation pathway upon $420 \mathrm{~nm}$, an electron transfer from the [Zn(TPPS) $]^{4-}$ LUMO* to the poly[Ni(SalPhen)] LUMO occurs, followed by the collection of the resulting electron at the anode (Figure $6 \mathrm{a})$. The oxidation of the $[\mathrm{Zn}(\mathrm{TPPS})]^{4-}$, which is known to result in a formation of the $\pi$-delocalized radical cation rather than the metal-centred oxidized state [43], is compensated by an electron transfer from the Asc ${ }^{-}$molecule from the solution. In case of poly[Ni(SalPhen)] excitation, which occurs at both wavelengths, an electron transfer from the HOMO of the [Zn(TPPS) ${ }^{4-}$ to the HOMO* of the poly[Ni(SalPhen)], followed by the reduction of the [Zn(TPPS) $]^{4-}$ by $\mathrm{Asc}^{-}$and collection of the electron at the anode (Figure $6 \mathrm{~b}$ ). Both mechanisms propose the photoinduced electron transfer from $[\mathrm{Zn}(\mathrm{TPPS})]^{4-}$ to the polymer, which explains an anomalously low PE activity of the porphyrin doped films in ORR compared for the pristine ones; while the holes generated in the pristine NiSalen polymers are mobile due to the p-type conductivity of the polymer, in the porphyrin-doped polymers holes are trapped on the $[\mathrm{Zn}(\mathrm{TPPS})]^{4-}$ species and cannot be collected in the outer circuit.

(a)

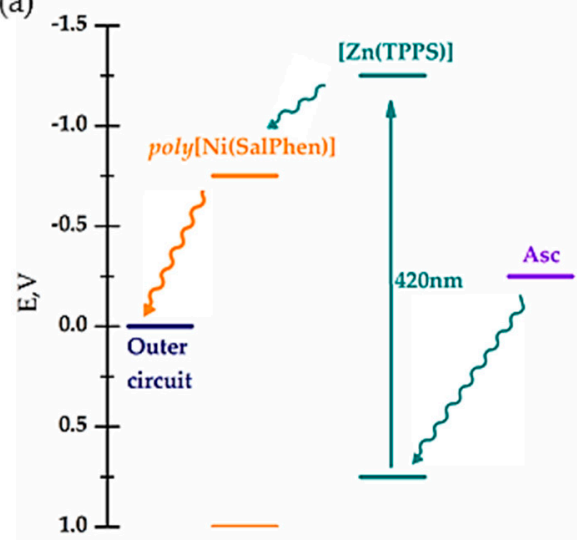

(b)

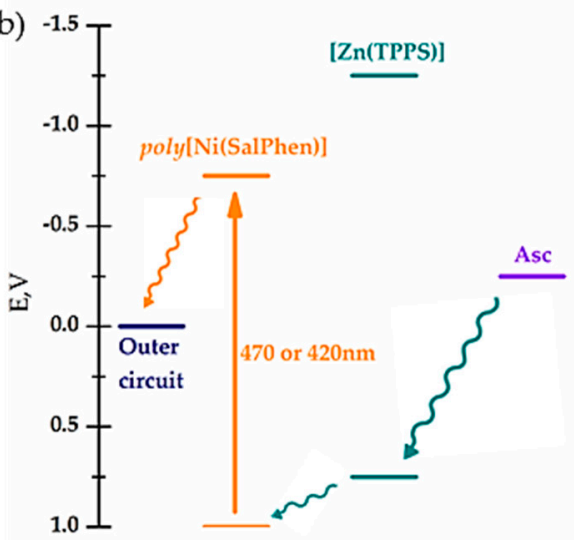

Figure 6. Plausible mechanism of ascorbate oxidation on the poly[Ni(SalPhen)]:[ZnTPPS] photoanode for (a) excitation of porphyrin or (b) excitation of NiSalen polymer.

\section{Materials and Methods}

All reagents and $\mathrm{Et}_{4} \mathrm{NBF}_{4}$ salt were purchased from Sigma-Aldrich or ABCR. All monomers were synthetized by the procedure of Pfeiffer [44] from commercially available aldehydes and diamines. HPLC grade acetonitrile and deionized water from Merck Milli-Q 
system were used for electrolyte solutions. All electrochemical experiments were performed on Autolab PGstat 302, Ag/ $\mathrm{Ag}^{+}$non-aqueous reference electrode MF-2062 (Bio Analytical Systems, USA) filled with $10 \mathrm{mM} \mathrm{AgNO}_{3}$ in $0.1 \mathrm{M} \mathrm{Et}_{4} \mathrm{NBF}_{4}$ in acetonitrile. $\mathrm{Ag} / \mathrm{AgCl}(\mathrm{KCl}$ sat.) reference electrode was used for aqueous solutions. UV-Vis spectra were recorded on a Shimadzu UV-1800 double-beam spectrophotometer in $1 \mathrm{~cm}$ quarz cuvettes.

Before each experiment, the ITO substrates were cleaned by 5 min ultrasonication in isopropanol, followed by deionized water rinsing and RCA cleaning protocol: 1:5:1 $(\mathrm{v} / \mathrm{v})$ $\mathrm{NH}_{3}(\mathrm{aq}) / \mathrm{H}_{2} \mathrm{O} / \mathrm{H}_{2} \mathrm{O}_{2}(\mathrm{aq})$ at $80{ }^{\circ} \mathrm{C}$ for $10 \mathrm{~min}$. After that, the substrates were washed with deionized water and dried at room temperature. Active area of the ITO was limited to $1 \mathrm{~cm}^{2}$ by Parafilm mask. Polymers were deposited on the ITO glass electrodes in three-electrode cell with platinum as the counter electrode and $\mathrm{Ag} / \mathrm{AgNO}_{3}$ as reference electrode from $1 \mathrm{mM}$ solutions of selected monomer in $0.1 \mathrm{M} \mathrm{Et}_{4} \mathrm{NBF}_{4}$ of $0.05 \mathrm{M}$ of [Et $\mathrm{Et}_{4} \mathrm{~N}$ ][MTPPS] in acetonitrile. The depositions were carried out in the $\mathrm{CV}$ mode in the range from 0.2 to $1.2 \mathrm{~V}$ vs. $\mathrm{Ag} / \mathrm{AgCl}$ with the scan rate of $100 \mathrm{mV} \mathrm{s}^{-1}$.

For the PEC experiments [31], LED light sources with $\lambda_{\max }$ of 420 and $470 \mathrm{~nm}$ were used, mounted to afford an illuminance of the active zone of the electrode of 37,300 and $131,000 \mathrm{~lx}$, respectively unless other specified. Experiments were performed in threeelectrode cells with $0.25 \mathrm{~cm}^{2}$ platinum wire as a counter electrode and saturated $\mathrm{Ag} / \mathrm{AgCl}$ as reference electrode, using $0.1 \mathrm{M}$ phosphate buffer with $\mathrm{pH} 6.86$ at a fixed potential of $0.0 \mathrm{~V}$ vs. $\mathrm{Ag} / \mathrm{AgCl}$. For ORR experiments, a solution was bubbled with oxygen $(1 \mathrm{~atm}$.) for $15 \mathrm{~min}$, and then an atmosphere of $1 \mathrm{~atm} . \mathrm{O}_{2}$ was maintained in the cell headspace during the experiment. For Asc ${ }^{-}$oxidation experiments [45], ascorbic acid was added to $100 \mathrm{mM}$ resulting concentration, then a solution was degassed by Ar bubbling for $15 \mathrm{~min}$, and an Ar atmosphere was maintained in the cell headspace during the experiment.

\section{Conclusions}

We report the photogalvanic effect demonstrated by pristine and porphyrin-doped NiSalen polymers in aqueous electrolyte solutions. While pristine polymeric films undergo cathodic photopolarization and generate photocurrent by oxygen reduction, porphyrindoped films are virtually unable to reduce oxygen. Instead, an anodic polarization was demonstrated for these films, which provides an ability for the photoelectrochemical oxidation of ascorbic acid. Introduction of porphyrinic dopants results in anodic photocurrent of $1.25 \mu \mathrm{A} \mathrm{cm}^{-1}$ in aqueous electrolyte containing ascorbate. The observed effect arises from the strongly donating behavior of porphyrin molecules, which serves as a hole acceptor.

Supplementary Materials: The following are available online at https:/ / www.mdpi.com/article/10 .3390 / catal11060729/s1, Figure S1: UV-Vis spectra of pristine and zinc porphyrin-doped NiSalen films; title, Figure S2: Oxygen reduction photocurrents on NiSalen polymer films; Figure S3: Photocurrents on poly[Ni(SalPhen)]+[Zn(TPPS)] films with irradiation at different range between diode (a) $470 \mathrm{~nm}$; (b) $420 \mathrm{~nm}$ ) and cell; Figure S4: The Tauc plots for calculating the optical bandgap of NiSalen complexes studied; Figure S5: The cyclic voltammetry of polymerization of pristine and doped NiSalen complexes.

Author Contributions: Conceptualization, D.A.L.; methodology, A.A.P., D.A.L. and O.V.L.; validation, A.A.P.; formal analysis, D.A.L.; investigation, A.A.P., E.V.A. and O.A.K.; resources, O.V.L.; data curation, A.A.P. and D.A.L.; writing-original draft preparation, A.A.P. and E.V.A.; writingreview and editing, D.A.L. and O.V.L.; visualization, A.A.P. and J.V.N.; supervision, D.A.L.; project administration, O.V.L.; funding acquisition, O.V.L and E.V.A. All authors have read and agreed to the published version of the manuscript.

Funding: This research was funded by Russian Foundation for Basic Research, grant number 18-0300864 (photovoltaic studies) and Russian Foundation for Basic Research, grant number 19-29-08026 (electrochemical studies).

Data Availability Statement: The data presented in this study are available upon request. 
Acknowledgments: The scientific research was partially performed at the Center for Optical and Laser materials research, Center for Chemical Analysis and Materials Research, Research Center for Magnetic Resonance of the Research Park of Saint Petersburg State University.

Conflicts of Interest: The authors declare no conflict of interest.

\section{References}

1. Deng, H.; Lin, L.; Ji, M.; Zhang, S.; Yang, M.; Fu, Q. Progress on the morphological control of conductive network in conductive polymer composites and the use as electroactive multifunctional materials. Prog. Polym. Sci. 2014, 39, 627-655. [CrossRef]

2. Luo, R.; Li, H.; Du, B.; Zhou, S.; Zhu, Y. A simple strategy for high stretchable, flexible and conductive polymer films based on PEDOT:PSS-PDMS blends. Org. Electron. 2020, 76, 105451. [CrossRef]

3. Dou, J.; Tang, L.; Mou, L.; Zhang, R.; Jiang, X. Stretchable conductive adhesives for connection of electronics in wearable devices based on metal-polymer conductors and carbon nanotubes. Compos. Sci. Technol. 2020, 197, 108237. [CrossRef]

4. Pankow, R.M.; Thompson, B.C. The development of conjugated polymers as the cornerstone of organic electronics. Polymer 2020, 207, 122874. [CrossRef]

5. Ostroverkhova, O. Organic Optoelectronic Materials: Mechanisms and Applications. Chem. Rev. 2016, 116, 13279-13412. [CrossRef]

6. Jamdegni, M.; Kaur, A. Highly efficient dark to transparent electrochromic electrode with charge storing ability based on polyaniline and functionalized nickel oxide composite linked through a binding agent. Electrochim. Acta 2020, 331, 135359. [CrossRef]

7. Díaz-Sánchez, J.; Roquero, P.; Hernández-Alcántara, J.M.; Rosas-Aburto, A.; Vázquez-Torres, H.; Gimeno, M. Complementary electrochromic devices of PANI and PEDOT using the enzymatic poly(gallic acid). Sol. Energy Mater. Sol. Cells 2019, $200,109973$. [CrossRef]

8. Tian, Y.; Dou, S.; Zhang, X.; Zhang, L.; Wang, L.; Zhao, J.; Zhao, X.; Li, Y. Synthesis of ordered bowl-like polyaniline film with enhanced electrochromic performances. Synth. Met. 2017, 232, 111-116. [CrossRef]

9. Mjejri, I.; Rougier, A. PEDOT:PSS $/ \mathrm{Fe}_{2} \mathrm{O}_{3}$ as hybrid composite film for tuning color in electrochromism. Mater. Today Proc. 2020, 33, 2470-2473. [CrossRef]

10. Lv, D.; Chen, W.; Shen, W.; Peng, M.; Zhang, X.; Wang, R.; Xu, L.; Xu, W.; Song, W.; Tan, R. Enhanced flexible room temperature ammonia sensor based on PEDOT: PSS thin film with $\mathrm{FeCl}_{3}$ additives prepared by inkjet printing. Sens. Actuators B Chem. 2019, 298, 126890. [CrossRef]

11. Martins, T.S.; Bott-Neto, J.L.; Raymundo-Pereira, P.A.; Ticianelli, E.A.; Machado, S.A.S. An electrochemical furosemide sensor based on pencil graphite surface modified with polymer film Ni-salen and $\mathrm{Ni}(\mathrm{OH})_{2} / \mathrm{C}$ nanoparticles. Sens. Actuators $B$ Chem. 2018, 276, 378-387. [CrossRef]

12. Pereira, C.F.; Olean-Oliveira, A.; David-Parra, D.N.; Teixeira, M.F.S. A chemiresistor sensor based on a cobalt(salen) metallopolymer for dissolved molecular oxygen. Talanta 2018, 190, 119-125. [CrossRef] [PubMed]

13. Inamdar, A.I.; Chavan, H.S.; Kim, H.; Im, H. Mesoporous Ni-PANI composite electrode for electrochromic energy storage applications. Sol. Energy Mater. Sol. Cells 2019, 201, 110121. [CrossRef]

14. Alekseeva, E.V.; Chepurnaya, I.A.; Malev, V.V.; Timonov, A.M.; Levin, O.V. Polymeric nickel complexes with salen-type ligands for modification of supercapacitor electrodes: Impedance studies of charge transfer and storage properties. Electrochim. Acta 2017, 225, 378-391. [CrossRef]

15. Vereshchagin, A.A.; Lukyanov, D.A.; Kulikov, I.R.; Panjwani, N.A.; Alekseeva, E.A.; Behrends, J.; Levin, O.V. The Fast and the Capacious: A [Ni(Salen)]-TEMPO Redox-Conducting Polymer for Organic Batteries. Batter. Supercaps 2021, 4, 336-346. [CrossRef]

16. Eliseeva, S.N.; Alekseeva, E.V.; Vereshchagin, A.A.; Volkov, A.I.; Vlasov, P.S.; Konev, A.S.; Levin, O.V. Nickel-Salen Type Polymers as Cathode Materials for Rechargeable Lithium Batteries. Macromol. Chem. Phys. 2017, 218, 1700361. [CrossRef]

17. Zhang, M.; Liu, Y.; Zhu, H.; Wang, X. Hierarchical bead chain $\mathrm{ZnFe}_{2} \mathrm{O}_{4}$-PEDOT composites with enhanced Li-ion storage properties as anode materials for lithium-ion batteries. Appl. Surf. Sci. 2020, 529, 147078. [CrossRef]

18. Oka, K.; Strietzel, C.; Emanuelsson, R.; Nishide, H.; Oyaizu, K.; Strømme, M.; Sjödin, M. Characterization of PEDOT-Quinone conducting redox polymers in water-in-salt electrolytes for safe and high-energy Li-ion batteries. Electrochem. Commun. 2019, 105, 106489. [CrossRef]

19. He, Y.; Aïch, B.R.; Lu, J.; Alem, S.; Lang, S.; Movileanu, R.; Baribeau, J.-M.; Tao, Y. A diketopyrrolopyrrole conjugated polymer based on 4,4'-difluoro-2,2'-bithiophene for organic thin-film transistors and organic photovoltaics. Thin Solid Films 2020, 711, 138300. [CrossRef]

20. Saeed, M.A.; Kim, S.H.; Lee, S.Y.; Shim, J.W. High indoor performance of flexible organic photovoltaics using polymer electrodes. Thin Solid Films 2020, 704, 138006. [CrossRef]

21. Ma, J.; Li, Y.; Li, J.; Qin, M.; Wu, X.; Lv, Z.; Hsu, Y.-J.; Lu, X.; Wu, Y.; Fang, G. Constructing highly efficient all-inorganic perovskite solar cells with efficiency exceeding $17 \%$ by using dopant-free polymeric electron-donor materials. Nano Energy 2020, 75, 104933. [CrossRef]

22. Wang, L.; Zhang, F.; Liu, T.; Zhang, W.; Li, Y.; Cai, B.; He, L.; Guo, Y.; Yang, X.; Xu, B.; et al. A crosslinked polymer as dopant-free hole-transport material for efficient n-i-p type perovskite solar cells. J. Energy Chem. 2021, 55, 211-218. [CrossRef] 
23. Han, Q.; Liu, S.; Liu, Y.; Jin, J.; Li, D.; Cheng, S.; Xiong, Y. Flexible counter electrodes with a composite carbon/metal nanowire/polymer structure for use in dye-sensitized solar cells. Sol. Energy 2020, 208, 469-479. [CrossRef]

24. Seema, H.; Zafar, Z.; Samreen, A. Evaluation of solution processable polymer reduced graphene oxide transparent films as counter electrodes for dye-sensitized solar cells. Arab. J. Chem. 2020, 13, 4978-4986. [CrossRef]

25. Giri, D.; Raut, S.K.; Patra, S.K. Diketopyrrolopyrrole/perylene-diimide and thiophene based D- $\pi$-A low bandgap polymer sensitizers for application in dye sensitized solar cells. Dye. Pigment. 2020, 174, 108032. [CrossRef]

26. Mansha, M.; Younas, M.; Gondal, M.A.; Ullah, N. 1,5-Naphthyridine-based conjugated polymers as co-sensitizers for dyesensitized solar cells. Sol. Energy 2019, 194, 682-687. [CrossRef]

27. Semenikhin, O.; Ovsyannikova, E.; Ehrenburg, M.; Alpatova, N.; Kazarinov, V. Electrochemical and photoelectrochemical behaviour of polythiophenes in non-aqueous solutions. J. Electroanal. Chem. 2000, 494, 1-11. [CrossRef]

28. Glenis, S.; Tourillon, G.; Garnier, F. Photoelectrochemical properties of thin films of polythiophene and derivatives: Doping level and structure effects. Thin Solid Films 1984, 122, 9-17. [CrossRef]

29. Semenikhin, O.A.; Ovsyannikova, E.V.; Alpatova, N.M.; Rotenberg, Z.A.; Kazarinov, V.E. Electrochemical and photoelectrochemical behaviour of poly-3-methylthiophene and polybithiophene in non-aqueous solutions. J. Electroanal. Chem. 1999, 463, 190-199. [CrossRef]

30. Smirnova, E.A.; Besedina, M.A.; Karushev, M.P.; Vasil'ev, V.V.; Timonov, A.M. Photogalvanic and photovoltaic effects in systems based on metal complexes of Schiff bases. Russ. J. Phys. Chem. A 2016, 90, 1088-1094. [CrossRef]

31. Konev, A.S.; Kayumov, M.Y.; Karushev, M.P.; Novoselova, Y.V.; Lukyanov, D.A.; Alekseeva, E.V.; Levin, O.V. Polymeric Metal Salen-Type Complexes as Catalysts for Photoelectrocatalytic Hydrogen Peroxide Production. ChemElectroChem 2018, 5, 3138-3142. [CrossRef]

32. Molino, P.J.; Garcia, L.; Stewart, E.M.; Lamaze, M.; Zhang, B.; Harris, A.R.; Winberg, P.; Wallace, G.G. PEDOT doped with algal, mammalian and synthetic dopants: Polymer properties, protein and cell interactions, and influence of electrical stimulation on neuronal cell differentiation. Biomater. Sci. 2018, 6, 1250-1261. [CrossRef] [PubMed]

33. Apraksin, R.V.; Volosatova, Y.A.; Volkov, A.I.; Vlasov, P.S.; Lukyanov, D.A.; Kulikov, I.R.; Eliseeva, S.N.; Levin, O.V. Electrochemical synthesis and characterization of poly $\left[\mathrm{Ni}\left(\mathrm{CH}_{3} \mathrm{Osalen}\right)\right]$ with immobilized poly(styrenesulfonate) anion dopants. Electrochim. Acta 2021, 368, 137637. [CrossRef]

34. Yan, W.; Jiang, D.; Liu, Q.; Kang, Q.; Zhou, F. Effects of doping methods and dopant sizes on the performance of solar cells constructed with anchor-guided photoelectrochemical polymerization of thiophene. Electrochim. Acta 2020, 330, 135250. [CrossRef]

35. Mahmoodian, M.; Pourabbas, B.; Mohajerzadeh, S. Effect of anionic dopants on thickness, morphology and electrical properties of polypyrrole ultra-thin films prepared by in situ chemical polymerization. Thin Solid Films 2015, 583, 255-263. [CrossRef]

36. Chen, J.; Wagner, P.; Tong, L.; Wallace, G.G.; Officer, D.L.; Swiegers, G.F. A Porphyrin-Doped Polymer Catalyzes Selective, Light-Assisted Water Oxidation in Seawater. Angew. Chem. Int. Ed. 2012, 51, 1907-1910. [CrossRef]

37. Liu, H.; Blankenship, R.E. On the interface of light-harvesting antenna complexes and reaction centers in oxygenic photosynthesis. Biochim. Biophys. Acta Bioenerg. 2019, 1860, 148079. [CrossRef]

38. El-Khouly, M.E. Energy transfer between two light harvesting phthalocyanine derivatives as model for artificial photosynthetic antenna: Laser photolysis studies. Spectrochim. Acta Part A Mol. Biomol. Spectrosc. 2018, 205, 508-513. [CrossRef]

39. Arrigo, A.; Puntoriero, F.; La Ganga, G.; Campagna, S.; Burian, M.; Bernstorff, S.; Amenitsch, H. Aggregation-Induced Energy Transfer in a Decanuclear Os(II)/Ru(II) Polypyridine Light-Harvesting Antenna Dendrimer. Chem 2017, 3, 494-508. [CrossRef]

40. Hambright, P.; Chock, P.B. Metal-porphyrin interactions. III. Dissociative-interchange mechanism for metal ion incorporation into porphyrin molecules. J. Am. Chem. Soc. 1974, 96, 3123-3131. [CrossRef]

41. Peters, M.K.; Herges, R. Insertion of Ni(I) into Porphyrins at Room Temperature: Preparation of Ni(II)porphyrins, and $\mathrm{Ni}(\mathrm{II})$ chlorins and Observation of Hydroporphyrin Intermediates. Inorg. Chem. 2018, 57, 3177-3182. [CrossRef] [PubMed]

42. Mergen, Ö.B.; Arda, E. Determination of Optical Band Gap Energies of CS/MWCNT Bio-nanocomposites by Tauc and ASF Methods. Synth. Met. 2020, 269, 116539. [CrossRef]

43. Neumann-Spallart, M.; Kalyanasundaram, K. On the One and Two-Electron Oxidations of Water-Soluble Zinc Porphyrins in Aqueous Media. Z. Nat. B 1981, 36, 596-600. [CrossRef]

44. Pfeiffer, P.; Breith, E.; Lübbe, E.; Tsumaki, T. Tricyclische orthokondensierte Nebenvalenzringe. Justus Liebig's Ann. Chem. 1933, 503, 84-130. [CrossRef]

45. Lee, M.H.; Kim, J.W.; Lee, C.Y. Fullerene-porphyrin-ferrocene triad self-assembled monolayers (SAMs) for photovoltaic applications. J. Organomet. Chem. 2014, 761, 20-27. [CrossRef] 